Received 27.10.2016 Reviewed 28.11.2016 Accepted 16.02.2017

A - study design

B - data collection

C - statistical analysis

D - data interpretation

E - manuscript preparation

$\mathbf{F}$ - literature search

\title{
Recharging infiltration of precipitation water through the light soil, in the absence of surface runoff
}

\author{
Franciszek CZYŻYK ${ }^{1) A B D E F} \bowtie$, Zbigniew ŚWIERKOT ${ }^{2) B E F}$
}

\footnotetext{
1) Institute of Technology and Life Sciences, Lower Silesian Research Centre in Wrocław, Berlinga 7, 51-209 Wrocław, Poland; e-mail f.czyzyk@itp.edu.pl

2) Plant of Sanitary Systems and Road Construction, Sulmierzycka 1, 51-127 Wrocław, Poland
}

For citation: Czyżyk F., Świerkot Z. 2017. Recharging infiltration of precipitation water through the light soil, in the absence of surface runoff. Journal of Water and Land Development. No. 32 p. 25-30. DOI: 10.1515/jwld-20170003 .

\begin{abstract}
The article presents the value of recharging infiltration of precipitation through the light soil and its distribution over time, based on five-year of lysimetric research. The effect of organic and mineral fertilization on the infiltration was studied. In lysimeters does not occur the phenomenon of surface runoff, and thus, by analogy, the results of the research can be applied to agriculturally used lowland areas with sandy soils. The results showed that the infiltration is very changeable in time. On its value, in addition to precipitation, the greatest influence has evapotranspiration. The largest infiltration occurs in March after the spring thaws $(I E=70-81 \%$ monthly precipitation) and the smallest in August ( $I E=1.2-15.0 \%$ precipitation, depending on the type of fertilizer used and the level of fertilization). The soil fertilization, especially by using organic fertilizer (compost), is a factor, which has significantly influence on reduction of the recharging infiltration. The soil fertilization with compost reduced the infiltration of 7.4-9.0\%, and with mineral fertilization of $5.4-7.0 \%$ of annual precipitation totals, compared with the infiltration through the soil not fertilized. The average annual index of infiltration was $21.8-25.3 \%$ of annual precipitation totals in variant of soil fertilized and $30.7 \%$ in case of the soil not fertilized.
\end{abstract}

Key words: infiltration, light soil, precipitation, water resources

\section{INTRODUCTION}

Groundwater resources are supplied and recharged by precipitation penetrated deep into the soil. One of methods for the groundwater resources renewable determination it is to estimate the effective rainfall infiltration of the first water - bearing level [HERBICH et al. 2013; TARKA 2001]. According to the Dictionary of Hydrogeological, published by Polish Geological Institute a rainfall effective (successful) it is a part of the water coming from precipitation which after reduction of the volume associated with runoff, evapotranspiration and with the process of molecular binding forces of the soil grains in the unsaturated zone, gets into the saturation zone and groundwater supplies [BoCHEŃSKA et al. 2002].
Effective infiltration (IE) can be expressed by the following formula:

$$
I E=P-S-E T-R
$$

where: $P=$ precipitation, $S=$ surface runoff, $E T=$ evapotranspiration, $R=$ molecularly bound water in the soil (ground).

An infiltration and a level of groundwater supply depends mainly on size of precipitation, the permeability of the soil, retention properties, landform and its plant cover, surface runoff and evapotranspiration. Precipitation can soak into the soil and penetrate into the groundwater run down to the surface receivers and back to the atmosphere by field evaporation processes 
(evaporation from the free surface of the water and the soil, transpiration and sublimation).The decisive factor in the distribution of rainfall for the different phases of water cycle has an active surface formed by soils and vegetation. In addition to the size of the active surface area of precipitation affects the intensity of infiltration, surface runoff and soil retention [MiCHALCZYK 2004]. Elements of water balance also largely depend on catchment usage [GRAF, KRAJEWSKI 2013; MIODUSZEWSKI 2009]. The amount of rainwater infiltrated groundwater also depends on the type of agriculture fertilizers used and fertilization level [CZYŻYK, RAJMUND 2013; 2014]. Renewability of groundwater resources is the result of many factors and it is practically difficult to determine precisely. This applies especially to areas of varying land shape, high soil volatility and changing in soil use. To determine the sustainability of groundwater resource they use different methods mainly based on determining the rate of infiltration linked with the type of rock (ground) and layers of subsurface lithology or for the analysis of natural fluctuations of the water level in hydrogeological holes. Reported in the literature evaluation of renewable sources of groundwater, are determined by various methods, so they are so widely divergent [PACZYŃSKI et al. 1996; TARKA 2001]. The effective infiltration in the catchment plains with a single type of soil can be assessed relatively accurately. On the flat the plain with well permeable light soils, surface runoff do not occur or are negligible and are not a significant element of water balance. In this study the size and time distribution of effective infiltration of rainwater through the soil light, established by method of lysimetric studies, conducted in the five-years period are presented.

Lysimeters conditions were similar to natural field conditions in lowland area, where there is no runoff of rainwater. The actual volume of rainwater infiltrated aquifer is practically immeasurable using methods of the field. Lysimeter studies allow measure its precise.

\section{MATERIALS AND METHODS}

The study was conducted from April 1, 2002 to March 31, 2007, in lysimeters filled with slightly loamy, containing $13 \%$ of earthy fraction parts $(<0.02$ $\mathrm{mm}), 24.8 \%$ of the dust parts $(0.02-0.1 \mathrm{~mm})$ and $62.2 \%$ of sand $(0.1-1.0 \mathrm{~mm})$. Lysimeters with a diameter of $100 \mathrm{~cm}$ and $130 \mathrm{~cm}$ deep are completely submerged in the ground. The soil in the lysimeters was fertilized with two types of fertilizers (compost and mineral fertilizers). The conditions in the lysimeters were similar to the natural conditions of the land used for agricultural purposes (crop rotation and fertilization). In subsequent years, the research lysimeters were sown with a mix of grasses, corn, sugar beets, yellow mustard and triticale. In order to investigate the effect of the fertilizer applied on infiltration following variants were used: "0" - without fertilization, two variants with organic fertilizing using compost $\mathrm{K} 1-10 \mathrm{~g} \mathrm{~N} \cdot \mathrm{m}^{-2}$, and $\mathrm{K} 2-15 \mathrm{~g} \mathrm{~N} \cdot \mathrm{m}^{-2}$, and two variants of mineral fertilization: NPK1 and NPK2 and the equivalent doses of $\mathrm{N}$ in the form of ammonium nitrate and PK in the form of superphosphate and potassium salt. All variants were introduced in triplicate. The research began in the last days of March 2002 under full soil moisture (the moment of the disappearance of lysimeters leachate), and was completed at the turn of March and April 2007 in the same moisture conditions. In this case, spreads rainwater from the entire study does not take into account the volume of water retained in the soil.

\section{RESULTS AND DISCUSSION}

Individual years of the study period were significantly different in terms of size of precipitation (Tab. 1). Assuming that in the area of Wroclaw annual rainfall are less than $500 \mathrm{~mm}$, with a probability of 50$100 \%$, refer to dry years, the year 2003 can be considered to be dry [DUBICKI et al. 2002].Years of total precipitation exceeding $600 \mathrm{~mm}$ are included while the wet so $2005(697.5 \mathrm{~mm})$ and $2006(613.7 \mathrm{~mm})$ years were wet. Other years can be classified in terms of the average size of precipitation. More accurate assessment of the conditions of precipitation (humidity) is obtained using the criteria defined by KACZOROWSKA [1962] according to which the individual years are:

- average, if the annual rainfall is between $90-110 \%$ of average of sum in a long-term,

- dry when total precipitation is $75-90 \%$ of average of sum in a long-term,

Table 1. Precipitations $(\mathrm{mm})$ at the Research Station of the Institute of Technology and Life Sciences in Kamieniec Wroclawski in the years 2002-2007

\begin{tabular}{|c|c|c|c|c|c|c|c|c|c|c|c|c|c|}
\hline \multirow{2}{*}{ Years } & \multicolumn{12}{|c|}{ Precipitations in months } & \multirow{2}{*}{$\begin{array}{c}\text { Annual precipi } \\
\text { tation I-XII }\end{array}$} \\
\hline & I & II & III & IV & $\mathrm{V}$ & VI & VII & VIII & IX & $\mathrm{X}$ & $\mathrm{XI}$ & XII & \\
\hline 2002 & $\begin{array}{lllllllllll}- & \end{array}$ & - & - & 32.9 & 37.1 & 68.2 & 49.5 & 78.7 & 52.2 & 61.2 & 52.3 & 16.2 & $448.3^{1)}$ \\
\hline 2003 & 40.0 & 2.8 & 18.7 & 11.9 & 80.5 & 24.3 & 58.8 & 55.3 & 42.4 & 51.5 & 27.8 & 47.3 & 461.3 \\
\hline 2004 & 31.2 & 60.6 & 56.6 & 24.5 & 35.2 & 40.5 & 88.5 & 50.8 & 21.8 & 45.6 & 81.4 & 15.4 & 552.1 \\
\hline 2005 & 46.2 & 51.2 & 11.5 & 27.0 & 150.8 & 46.8 & 122.6 & 54.4 & 24.9 & 6.7 & 31.0 & 106.4 & 679.5 \\
\hline 2006 & 28.9 & 43.7 & 26.1 & 54.2 & 21.9 & 56.6 & 12.0 & 179.3 & 20.3 & 68.4 & 65.6 & 36.7 & 613.7 \\
\hline 2007 & 64.6 & 53.3 & 55.5 & - & - & - & - & - & - & - & - & - & $173.4^{2)}$ \\
\hline Sum & 210.9 & 211.6 & 168.4 & 150.5 & 325.5 & 236.4 & 331.4 & 418.5 & 161.6 & 233.4 & 258.1 & 222.0 & 2928.3 \\
\hline
\end{tabular}

1) Total precipitation from the period IV-XII. ${ }^{2)}$ Total precipitation from the period I-III.

Source: own study. 
- very dry when total precipitation is less than $75 \%$ of average of sum in a long-term,

- wet, when total precipitation is $110-125 \%$ of average of sum in a long-term,

- very wet when total precipitation is more than $125 \%$ of average of sum in a long-term.

From Figure 1, developed according to these criteria, it appears that during the study years 2002,2004 and 2006 were average in terms of the conditions of precipitation, whereas 2003 was dry and 2005 was wet. Half of spring-summer (April-September) was average in the 2002-2003, dry in 2004, and wet in 2005 and 2006 years.

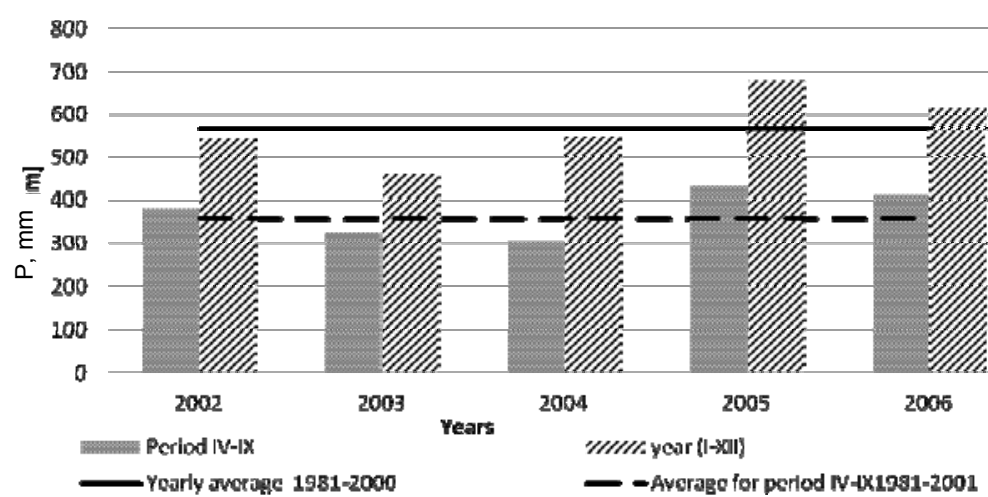

Fig. 1. Precipitation variability in the years 2001-2006 in relation to the years 1981-2000 in Wrocław; source: own study

In particular years of study there were dry periods with little rainfall and months of very heavy rain like May, July and December 2005 and August of 2006. Lysimeters leachates, which are part of the precipitation penetrating the sandy soil to a depth of $130 \mathrm{~cm}$, occurred at a very high volatility.

Those quantity of leachates dependent not only on amount of precipitation, but season and humidity of the soil. The leachates appeared with a variable delay with respect to the occurrence of heavy rainfall. Under studies delay was not large and ranged from several hours to two days after the onset of precipitation, depending on a preceding state of soil moisture. In the winter months when rainfall was in the form of snow, and the soil was frozen, the delay depended on the duration of such conditions. That is why the biggest infiltration occurred in March, after the thaw internal, despite the fact that March was not the month with the biggest precipitation. Infiltration scale, the volume of effluent expressed in $\mathrm{dm}^{3} \cdot \mathrm{m}^{-2}$, examined variants (Tab. 2) is characterized by very high volatility. During the months of late autumn and in the winter months, in all study period, there were the greatest volume of leachates, which were from about 40 to more than $80 \%$ the amount of precipitation (Tab. 3). It is a period when the scale of infiltration depended on the size of precipitation to the greatest extent. A close correlation between the amount of rainfall and infiltration showed many authors including works DYNOWSKA and TLAŁKA [1982], NowAK [2007],
BUCZYŃSKI and WCISŁO [2013]. According BUCZYŃSKI and WCISŁO [2013] the biggest raising of the ground water (the largest infiltration) occurred during the spring thaw and summer high rainfall. The results of lysimeter experiments showed the biggest infiltration in March (Fig. 2) after spring thaw. During the growing season the dependence of size infiltration from precipitation decreased. In some months of this period, especially from August to October in variants of soil fertilized appeared almost complete disappearance of infiltration despite the fact that August was the month with the largest sum of precipitation. Under experimental lysimeter conditions (with no surface runoff) measurements started and ended at the moment the same humidity conditions. In this situation, the only outflow elements of rainwater remain effective are an infiltration and evapotranspiration.

The results showed the overwhelming superiority of evapotranspiration over the effective infiltration $(I E=21.8$ $30.7 \%$ of annual precipitation). Similar proportions of these elements of the water balance showed GRAF and KRAJEWSKI [2013] in Mogilnica catchment experiments (basin of Warta), where evapotranspiration was $79 \%$, infiltration $15 \%$ and surface runoff $6 \%$ of annual precipitation. According to KANECKAGESZKE and ŁABĘDZKI [2006] average value of evapotranspiration on a sugar beet plantation in the area of Wrocław, ranged from 363 to $440 \mathrm{~mm}$ per year. In cited results of lysimeter experiments with sugar beet plants were grown in 2004. The amount of evapotranspiration calculated (based on data from Table 1 and 2) in this year were similar to cited above and ranged from 396 to $433 \mathrm{~mm}$.

The results of showed study indicate that the decisive factor in the level of infiltration is evapotranspiration, which mainly depends on climatic conditions and land covering by plants and how to use it. In areas used for agriculture big impact on evapotranspiration size is obtained yields [ŁABĘDZKI 1997; MLADENOVA, VARLEV 2007; SZAJDA, ŁABĘDZKI 2016]. According to LABĘDZKI [1997] relation between the yield and the evapotranspiration is close to linear. The crop yields, and therefore infiltration and evapotranspiration primarily affects fertilization of the soil.

The results of lysimeter experiment showed that infiltration by light unfertilized soil was $30.7 \%$ of annual sum of precipitation, and to soil fertilized $21.8-25.3 \%$, depending on kind and dose of fertilizer (Tab. 3, Fig. 3). The results in this paper can by analogy applied to agricultural use lowland, with sandy soils and shallow aquifers. The sandy soils are characterized by the highest indicators of infiltration. TARKA [2001] determining infiltration factors for the catchment with sandstone formations, received its relatively wide range of from 17.0 to $39.1 \%$ of the average annual rainfall in this area. 
Table 2. The monthly and annuals volume of effluents from particular fertilization variants in the period of April 2002March 2007

\begin{tabular}{|c|c|c|c|c|c|c|c|c|c|c|c|c|c|}
\hline \multirow{2}{*}{ Years } & \multicolumn{13}{|c|}{ Volume of effluents, $\mathrm{dm}^{3}$} \\
\hline & $\mathrm{I}$ & II & III & IV & $\mathrm{V}$ & VI & VII & VIII & IX & $\mathrm{X}$ & $\mathrm{XI}$ & XII & $\mathrm{I}-\mathrm{XII}$ \\
\hline \multicolumn{14}{|c|}{ Variant 0 (without fertilization) } \\
\hline 2002 & - & - & $\begin{array}{llll}- & \\
\end{array}$ & 16.0 & 12.1 & 18.9 & 2.2 & 20.4 & 5.3 & 1.8 & 15.0 & 14.0 & 105.7 \\
\hline 2003 & 27.4 & 7.6 & 17.8 & 5.2 & 21.7 & 3.8 & 2.5 & 0.0 & 0.0 & 1.9 & 0.4 & 18.0 & 106.3 \\
\hline 2004 & 35.7 & 31.5 & 30.6 & 14.6 & 7.6 & 1.9 & 4.8 & 6.9 & 1.3 & 0.0 & 17.8 & 3.2 & 155.9 \\
\hline 2005 & 14.4 & 11.2 & 19.1 & 4.5 & 40.5 & 17.5 & 15.9 & 15.5 & 5.5 & 0.0 & 0.0 & 42.7 & 186.8 \\
\hline 2006 & 9.9 & 22.9 & 36.6 & 3.9 & 4.8 & 1.3 & 0.0 & 22.3 & 0.0 & 10.2 & 47.5 & 21.3 & 180.7 \\
\hline 2007 & 20.0 & 31.6 & 32.0 & - & - & - & - & - & - & - & - & - & 83.6 \\
\hline Average & 21.5 & 21.0 & 27.2 & 8.8 & 17.3 & 8.7 & 5.1 & 13.0 & 2.4 & 2.8 & 16.1 & 19.8 & 163.8 \\
\hline \multicolumn{14}{|c|}{ Variant K1 (organic fertilization, compost $-10 \mathrm{~g} \mathrm{~N}^{-\mathrm{m}^{-2}}$ ) } \\
\hline 2002 & - & - & - & 5.1 & 6.8 & 3.4 & 1.6 & 1.0 & 0.0 & 0.0 & 10.6 & 18.7 & 47.2 \\
\hline 2003 & 20.0 & 9.0 & 9.0 & 3.2 & 17.6 & 3.8 & 2.5 & 0.0 & 0.0 & 0.0 & 0.0 & 18.9 & 84.0 \\
\hline 2004 & 31.2 & 31.8 & 33.8 & 11.0 & 6.4 & 3.2 & 3.2 & 0.0 & 0.0 & 0.0 & 0.0 & 3.1 & 123.7 \\
\hline 2005 & 9.4 & 13.1 & 20.4 & 3.1 & 43.3 & 26.1 & 5.7 & 0.0 & 0.0 & 0.0 & 0.0 & 21.7 & 142.8 \\
\hline 2006 & 7.6 & 11.8 & 24.5 & 4.1 & 1.1 & 0.0 & 0.0 & 5.7 & 5.0 & 6.4 & 39.0 & 15.9 & 121.1 \\
\hline 2007 & 20.0 & 29.9 & 30.6 & - & - & - & - & - & - & - & - & - & 80.5 \\
\hline Average & 17.6 & 19.1 & 23.7 & 5.3 & 15.0 & 7.3 & 2.6 & 1.3 & 1.0 & 1.3 & 9.9 & 15.7 & 119.9 \\
\hline \multicolumn{14}{|c|}{ Variant K2 (organic fertilization, compost $-15 \mathrm{~g} \mathrm{~N} \cdot \mathrm{m}^{-2}$ ) } \\
\hline 2002 & - & - & - & 6.1 & 5.4 & 2.8 & 0.5 & 0.0 & 0.0 & 0.0 & 10.6 & 11.5 & 36.9 \\
\hline 2003 & 17.7 & 9.0 & 8.9 & 3.4 & 18.3 & 2.7 & 2.0 & 0.0 & 0.0 & 0.0 & 0.0 & 15.9 & 77.9 \\
\hline 2004 & 33.8 & 28.0 & 32.5 & 10.3 & 3.8 & 2.9 & 3.8 & 0.0 & 0.0 & 0.0 & 3.3 & 1.7 & 120.1 \\
\hline 2005 & 8.5 & 14.3 & 21.7 & 2.5 & 35.0 & 25.5 & 6.4 & 0.0 & 0.0 & 0.0 & 0.0 & 17.6 & 131.5 \\
\hline 2006 & 9.3 & 13.6 & 25.1 & 2.9 & 1.0 & 0.0 & 0.0 & 5.1 & 5.1 & 5.7 & 33.8 & 10.4 & 112.0 \\
\hline 2007 & 17.8 & 29.6 & 29.9 & - & - & - & - & - & - & - & - & - & 77.3 \\
\hline Average & 17.4 & 18.9 & 23.6 & 5.0 & 12.7 & 6.8 & 2.5 & 1.0 & 1.0 & 1.1 & 9.5 & 11.4 & 111.1 \\
\hline \multicolumn{14}{|c|}{ Variant NPK1 (mineral fertilization $-10 \mathrm{~g} \mathrm{~N} \cdot \mathrm{m}^{-2}$ ) } \\
\hline 2002 & - & - & - & 14.0 & 7.9 & 2.5 & 0.6 & 0.3 & 0.0 & 0.0 & 11.0 & 21.0 & 57.3 \\
\hline 2003 & 18.5 & 6.6 & 9.3 & 5.2 & 19.1 & 3.8 & 2.5 & 0.0 & 0.0 & 0.0 & 0.0 & 19.1 & 84.1 \\
\hline 2004 & 34.4 & 32.5 & 33.6 & 10.4 & 8.9 & 3.2 & 3.2 & 0.0 & 0.0 & 0.0 & 0.0 & 2.5 & 128.7 \\
\hline 2005 & 10.6 & 15.9 & 21.0 & 4.4 & 43.3 & 26.4 & 7.3 & 0.0 & 0.0 & 0.0 & 0.0 & 23.6 & 152.5 \\
\hline 2006 & 8.5 & 13.4 & 26.8 & 4.4 & 1.1 & 0.0 & 0.0 & 7.6 & 7.0 & 7.5 & 44.2 & 18.7 & 139.2 \\
\hline 2007 & 21.6 & 32.0 & 32.6 & - & - & - & - & - & - & - & - & - & 86.2 \\
\hline Average & 18.7 & 20.1 & 24.7 & 7.7 & 16.1 & 7.2 & 2.7 & 1.6 & 1.4 & 1.5 & 11.0 & 17.0 & 129.6 \\
\hline \multicolumn{14}{|c|}{ Variant NPK2 (mineral fertilization $-15 \mathrm{~g} \mathrm{~N} \cdot \mathrm{m}^{-2}$ ) } \\
\hline 2002 & - & - & - & 9.6 & 8.9 & 5.5 & 0.4 & 0.8 & 0.8 & 0.0 & 12.1 & 15.2 & 53.3 \\
\hline 2003 & 18.5 & 9.3 & 9.3 & 3.2 & 19.1 & 2.9 & 2.2 & 0.0 & 0.0 & 0.0 & 0.5 & 17.3 & 82.3 \\
\hline 2004 & 34.4 & 29.9 & 31.0 & 9.6 & 3.8 & 1.9 & 4.1 & 1.5 & 0.0 & 0.0 & 0.0 & 3.2 & 119.4 \\
\hline 2005 & 9.9 & 11.7 & 23.6 & 4.5 & 38.7 & 24.8 & 6.6 & 0.5 & 0.6 & 0.0 & 0.0 & 19.9 & 140.8 \\
\hline 2006 & 10.4 & 17.7 & 25.5 & 2.8 & 1.3 & 2.3 & 0.0 & 5.1 & 6.0 & 7.3 & 35.7 & 16.6 & 130.7 \\
\hline 2007 & 19.5 & 30.6 & 30.8 & - & - & - & - & - & - & - & - & - & 80.9 \\
\hline Average & 18.5 & 19.8 & 24.0 & 5.9 & 14.4 & 7.5 & 2.7 & 1.6 & 1.5 & 1.5 & 9.7 & 14.4 & 121.5 \\
\hline
\end{tabular}

Source: own study.

Table 3. Average monthly and annual recharging infiltration in the period April 2002-March 2007

\begin{tabular}{|c|c|c|c|c|c|c|c|c|c|c|c|c|c|}
\hline \multirow{2}{*}{ Variant } & \multicolumn{13}{|c|}{ Recharging infiltration in \% precipitation totals } \\
\hline & I & II & III & IV & $\mathrm{V}$ & VI & VII & VIII & IX & $\mathrm{X}$ & $\mathrm{XI}$ & XII & average \\
\hline 0 & 50.9 & 49.5 & 80.8 & 29.4 & 26.6 & 18.4 & 7.7 & 15.6 & 7.5 & 6.0 & 31.3 & 44.7 & 30.7 \\
\hline $\mathrm{K} 1$ & 41.8 & 45.2 & 70.2 & 17.6 & 23.1 & 15.4 & 3.9 & 1.6 & 3.1 & 2.7 & 19.2 & 35.3 & 23.3 \\
\hline $\mathrm{K} 2$ & 41.3 & 44.7 & 70.1 & 16.7 & 19.5 & 14.3 & 3.8 & 1.2 & 3.2 & 2.4 & 18.5 & 25.9 & 21.8 \\
\hline NPK1 & 44.4 & 47.4 & 73.2 & 25.5 & 24.7 & 15.2 & 4.1 & 1.9 & 4.3 & 3.2 & 21.4 & 38.2 & 25.3 \\
\hline NPK2 & 44.0 & 46.9 & 71.4 & 19.7 & 22.1 & 15.8 & 4.0 & 1.9 & 4.6 & 3.1 & 18.7 & 32.5 & 23.7 \\
\hline
\end{tabular}

Source: own study.

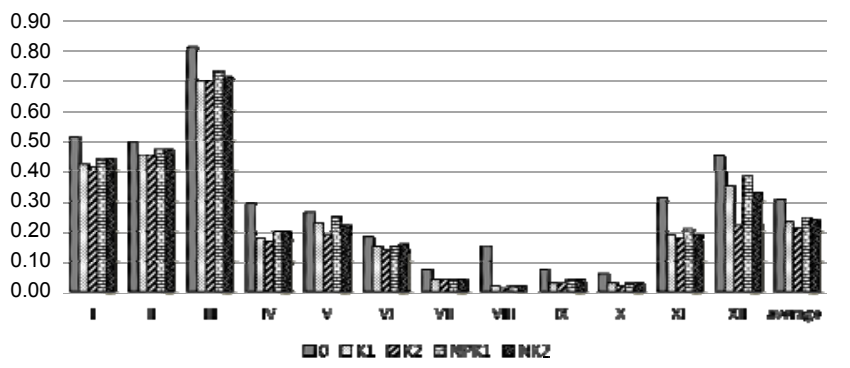

Fig. 2. Average indicators (monthly and annual) of recharging infiltration in the period April 2002-March 2007; source: own study 


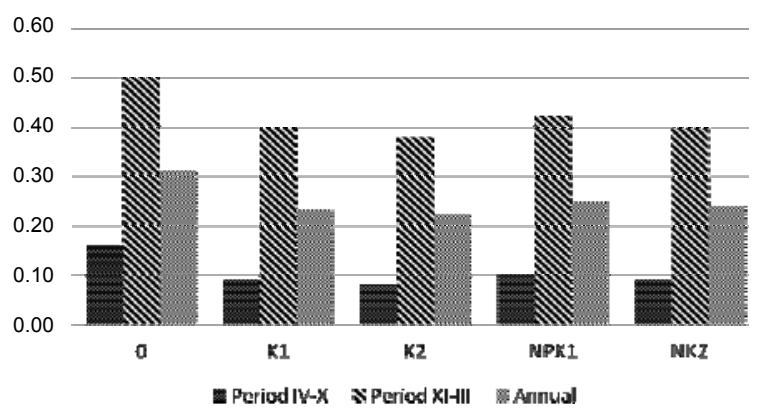

Fig. 3. Average indicators (periodic and annual) of recharging infiltration in the period April 2002-March 2007; source: own study

In lysimeter research discussed the range of infiltration estimate was much smaller and it is $21.8 \%$ to $30.7 \%$. There were no variability of soil. Variable element was only fertilization of the soil, which caused a decrease in infiltration in relation to infiltrate through the soil unfertilized. Under the conditions of fertilization, with equivalent doses of nitrogen supplied in organic fertilizer (compost), and mineral, obtained infiltration variation within $2 \%$. The organic fertilization decreased infiltration about 7.4-9.0\%, and mineral about $5.4-7.0 \%$ of sum of precipitation, relative to unfertilized soil.

\section{CONCLUSIONS}

1. In the absence of surface runoff the main elements of outflow precipitation: infiltration and evapotranspiration are effective. The balance between these elements show a clear advantage of evapotranspiration over the infiltration.

2. The amount of the effective infiltration, is very variable in time and to the greatest extent depends on the intensity of evapotranspiration. The largest infiltration occurs in March after the thaw of spring and lowest in August

3. During the period from August to October, effective infiltration is negligible and has no practical importance in the supply of groundwater precipitation.

4. Soil fertilization especially organic fertilizers, is an indirect factor for reducing infiltration. Fertilization increases plant yield, and thus increases evapotranspiration and reduces the effective infiltration.

\section{REFERENCES}

BocheńsKa T., DowgialŁo J., KLeCZKowski A.S., KRAJEWSKI S., MACIOSZCZYK A., RÓŻKOWSKI A., SADURSKI A., SZCZEPAŃSKI A., WITCZAK S. 2002. Słownik Hydrogeologiczny [Hydrogeological dictionary]. Warszawa. PIG. ISBN 83-86986-57-3 pp. 460.

BuCZYŃSKI S., WCISŁO M. 2013. Wpływ opadu i infiltracji na zasilanie paleogeńskich poziomów wodonośnych w skałach fliszowych Beskidu Sądeckiego [Influence of precipitation and infiltration on recharge the Paleogene aquifers of the Beskid Sądecki flysch]. Biuletyn Państwowego Instytutu Geologicznego. T. 456 p. 57-62.
CZYŻYK F., RAJMUND A. 2013. Water environment contamination by nitrogen and phosphorus as a result of an annual light soil fertilization. Ecological Chemistry and Engineering. A. Vol. 20(3) p. 373-381.

CZYŻYK F., RAJMUND A. 2014. Influence of agricultural utilization of sludge and compost from rural wastewater treatment plant on nitrogen passes in light soil. Polish Journal of Chemical Technology. Vol. 16. No. 1 p. 1-6.

DuBicki A., DuBICKA M., SZYMANOwSKI M. 2002. Klimat Wrocławia. W: Środowisko Wrocławia - Informator 2002 [The climat of Wrocław. In: Wrocław's environment - Directory 2002]. Wrocław. Dolnośląska Fundacja Ekorozwoju p. 9-25.

DynowsKa I., TLaŁKa A. 1982. Hydrografia [Hydrografy]. Warszawa. PWN. ISBN 83-01-03849-7 pp. 298.

GRAF R., KRAJEWSKI I. 2013. Kształtowanie się elementów bilansu wodnego w zlewni Mogilnicy na podstawie badań symulacyjnych [Forming of the water balance elements in the Mogilnica catchement on the basis of simulating investigations]. Nauka Przyroda Technologie. Vol. 7. Z. 1 p. 1-11.

Herbich P., KApuściński J., Nowicki K., Rodzoch A. 2013. Metodyka określania zasobów dyspozycyjnych wód podziemnych w obszarach bilansowych z uwzględnieniem potrzeb jednolitych bilansów wodno-gospodarczych. Poradnik metodyczny [Methodology for determining available resources of groundwater in the areas of balance with the needs of uniform water economic balances. Teaching guidelines]. Warszawa. Ministerstwo Środowiska. ISBN 978-83-63296-02-05 pp. 270.

KaCZOROwsKa Z. 1962. Opady w Polsce w przekroju wieloletnim [Precipitation in Poland in section of years]. Przegląd Geograficzny IGPAN. Nr 33 ss. 112.

KANECKA-GESZKE E., ŁABĘDZKI L. 2006. Ocena zagrożenia suszą uprawy buraka cukrowego w różnych rejonach agroklimatycznych Polski na glebach o różnej retencji użytkowej [Estimation of the drought risk for su gar beet crops in various agro-climatic regions of Poland and in the soils of different useful soil water retention]. Woda-Środowisko-Obszary Wiejskie. T. 6. Z. 1(16) p. 139157.

ŁABĘDZKI L. 1997. Potrzeby nawodnień użytków zielonych, uwarunkowania przyrodnicze i prognostyczne [The needs of grassland irrigation, natural and prognostic conditions]. Rozprawy Habilitacyjne. Falenty. Wydaw. IMUZ. ISBN 83-85735-51-8 pp. 170.

MichalcZYK Z. 2004. Rola obszarów wiejskich w tworzeniu i wykorzystaniu zasobów wodnych w Polsce [The role of rural areas in the formation and utilisation of water resources in Poland]. Woda-Środowisko-Obszary Wiejskie. T. 4. Z. 2a(11) p. 13-24.

MiodUSZEWSKI W. 2009. Water for agriculture and natural environment. Journal of Water and Land Development. No. 13b p. 3-13.

MLAdenOVA B., VARLEV I. 2007. Impact of extreme climate years on relative ,yield - evapotranspiration” relationships. Journal of Water and Land Development. No. 11 p. 71-77.

NOWAK A. 2007. Wpływ opadów atmosferycznych i temperatury powietrza na wahania stanu wód gruntowych w profilu Buk-Skórzewo-Poznań-Szczepankowo w latach 1961-1983 [The influence of precipitation and air temperature on the Groundwater table fluctuations in the profile of Buk-Skórzewo-Poznań-Szczepankowo in the years 1961-1983]. Badania Fizjograficzne nad Pol- 
ską Zachodnią. Ser. A. Geografia Fizyczna. T. 58 p. 159-168.

PaCZyŃSKi B., MacioszczyK T., KAZIMIERSKi B., MitrĘGA J. 1996. Ustalanie dyspozycyjnych zasobów wód podziemnych [Determination of available groundwater resources]. Poradnik metodyczny. Warszawa. MOŚZNiL. ISBN 83-86564-25-3 pp. 138.

SZAJDA J., ŁABĘDZKI L. 2016. Wyznaczanie ewapotranspiracji rzeczywistej użytków zielonych na podstawie ewapotranspiracji maksymalnej i potencjału wody w glebie
[Determination of actual evapotranspiration of grassland on the basis of maximum evapotranspiration and soil water potential]. Woda-Środowisko-Obszary Wiejskie. T. 16. Z. 1(53) p. 71-92.

TARKA R. 2001. Rozbieżności w ocenie zasobów odnawialnych wód podziemnych a przepuszczalność skał strefy przypowierzchniowej [Discrepancy in groundwater resources estimation and permeability of the surface zone]. Współczesne Problemy Hydrogeologii X. Wrocław. T. 1 p. 279-287.

\section{Franciszek CZYŻYK, Zbigniew ŚWIERKOT}

\section{Infiltracja efektywna wód opadowych przez glebę lekką w warunkach braku spływu powierzchniowego}

\section{STRESZCZENIE}

W pracy przedstawiono wielkość infiltracji efektywnej (IE) opadów atmosferycznych przez glebę lekką oraz jej rozkład w czasie na podstawie pięcioletnich badań lizymetrycznych. Badano też wpływ nawożenia organicznego i mineralnego na wielkość infiltracji. W warunkach lizymetrów nie występuje zjawisko spływu powierzchniowego, a więc przez analogię wyniki badań można odnieść do użytkowanych rolniczo terenów równinnych z glebami piaszczystymi. Wyniki badań świadcza, że wielkość infiltracji jest bardzo zmienna w czasie. Oprócz opadów atmosferycznych, w największym stopniu wpływa na nią ewapotranspiracja. Największa infiltracja występuje w marcu po roztopach wiosennych $(I E=70-81 \%$ opadu miesięcznego), a najmniejsza w sierpniu $(I E=$ $1,2-15 \%$ opadu, w zależności od rodzaju stosowanych nawozów i poziomu nawożenia). Nawożenie gleby, zwłaszcza nawozem organicznym (kompostem) jest czynnikiem mającym znaczący wpływ na zmniejszenie infiltracji efektywnej. Nawożenie gleby kompostem zmniejszyło infiltracje w porównaniu z notowaną przez glebę nienawożoną o 7,4-9,0\%, a nawozami mineralnymi o 5,4-7,0\% rocznej sumy opadów. Średni roczny wskaźnik infiltracji wyniósł 21,8-25,3\% sumy opadów w wariancie z glebą nawożoną i 30,7\% w wariancie kontrolnym (gleba nienawożona).

Slowa kluczowe: gleba lekka, infiltracja, opady atmosferyczne 